WellBeing International

WBI Studies Repository

$1-2012$

\title{
Clinical Anesthesia and Analgesia in Fish
}

Lynne U. Sneddon

University of Liverpool

Follow this and additional works at: https://www.wellbeingintlstudiesrepository.org/acwp_vsm

Part of the Animal Studies Commons, Other Animal Sciences Commons, and the Veterinary Toxicology and Pharmacology Commons

\section{Recommended Citation}

Sneddon, L. U. (2012). Clinical anesthesia and analgesia in fish. Journal of Exotic Pet Medicine, 21(1), 32-43.

This material is brought to you for free and open access by WellBeing International. It has been accepted for inclusion by an authorized administrator of the WBI Studies Repository. For more information, please contact wbisr-info@wellbeingintl.org.

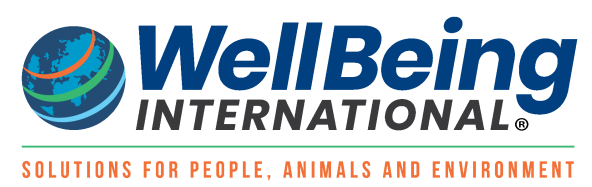




\title{
Clinical Anesthesia and Analgesia in Fish
}

\author{
Lynne U. Sneddon \\ University of Liverpool
}

\author{
KEYWORDS \\ Analgesics, anesthetic drugs, fish, local anesthetics, opioids, NSAIDs
}

\begin{abstract}
Fish have become a popular experimental model and companion animal, and are also farmed and caught for food. Thus, surgical and invasive procedures in this animal group are common, and this review will focus on the anesthesia and analgesia of fish. A variety of anesthetic agents are commonly applied to fish via immersion. Correct dosing can result in effective anesthesia for acute procedures as well as loss of consciousness for surgical interventions. Dose and anesthetic agent vary between species of fish and are further confounded by a variety of physiological parameters (e.g., body weight, physiological stress) as well as environmental conditions (e.g., water temperature). Combination anesthesia, where 2 anesthetic agents are used, has been effective for fish but is not routinely used because of a lack of experimental validation. Analgesia is a relatively underexplored issue in regards to fish medicine. However, recent studies have investigated opioid agents, nonsteroidal anti-inflammatory drugs, and local anesthetics to determine their efficacy in minimizing pain and discomfort. The opioid morphine and the local anesthetic lidocaine do have significant effectiveness in reducing pain-related responses in rainbow trout (Oncorhynchus mykiss). Studies aimed at developing reliable analgesic protocols should explore a wide range of analgesic drug classes in several fish species.
\end{abstract}

Recent research studies have suggested that fish are capable of nociception or pain perception. These investigations have demonstrated that bony (teleost) fish have nociceptors, receptors to detect potentially painful stimuli (Fig 1), which are very similar to those found in mammals. ${ }^{1-6}$ A variety of species also exhibit adverse behavioral and physiological responses to a potentially painful event ${ }^{7-12}$ that are ameliorated by the use of analgesia (Fig 2). ${ }^{13,14}$ Therefore, it would seem prudent to reduce any pain and discomfort during surgical interventions or when tissue damage has or is likely to occur. Anesthetic drugs have historically been used on fish in aquaculture, experimentation, and veterinary practice. ${ }^{15}$ Their use reduces the stressful impacts of handling, especially during routine procedures such as weighing, vaccination, blood sampling, tagging, experimental surgery, and veterinary procedures. Therefore, light anesthesia or sedation can improve the efficiency of rapid procedures. In invasive procedures in which tissue damage will occur, full or deep anesthesia or loss of consciousness is used to improve fish welfare and minimize the pain associated with surgical intervention. ${ }^{16-19}$ Anesthetic administration is usually achieved via immersion, with the drug being dissolved in water where the fish is held or an anesthetic vessel such as a tank or large bucket (also termed inhalation). When induction takes place through immersion, it is paramount to observe the fish and gauge the depth of anesthesia to reduce the incidence 
of overdose. Uptake of these chemicals is primarily via the gills and possibly the skin. The level of anesthesia is monitored by recording gill ventilation rates, maintenance of equilibrium (upright position), and reflex responses (e.g., swimming response to tail pinch). Research studies have measured rates of induction and recovery, responsiveness to external stimuli and handling, as well as pharmacokinetics of these agents. However, these research investigations often focus on a small range of species, testing only one anesthetic agent or a range of drugs on one species.

Analgesia has received much less attention, especially before $2003^{5}$; historically, fish were thought to be incapable of nociception or pain. ${ }^{20}$ However, studies are now trying to show the efficacy of analgesic medication in reducing or ameliorating any detrimental changes in behavior and physiology as a result of damage or noxious stimulation. This article will focus on what is known regarding anesthesia (primarily immersion) and analgesia in fish to provide an up-to-date account that can be referred to by scientists and veterinarians. Using the most efficient means of reducing stress and/or pain is crucial for the welfare of animals treated.

\section{ANESTHESIA IN FISH}

As with most other animals, induction and the depth of anesthesia in fish are generally divided into increasing stages or planes (Table 1). Monitoring of activity or swimming, posture, behavior, gill ventilation rate, eye movement, reflex responses, and heart rate is commonly done for fish; the degree of change desired will be dependent on the level of anesthesia required for a particular procedure. If induction is rapid, one can have difficulty differentiating one stage from another; therefore, use of the correct dose is particularly important to avoid overdose. For rapid and noninvasive procedures, light anesthesia can be sufficient (e.g., weighing, handling, inspection, gill scrape, external tagging). However, for invasive procedures and those of longer duration, surgical anesthesia is advised and may need to be accompanied by artificial ventilation of gills by flushing fresh or anesthetic-dosed water with a mouthpiece and pump when necessary. It is particularly important that the water is aerated and maintained at a similar temperature as its normal environment to avoid unnecessary stress to these poikilotherms. Hypoxia can elicit a stress response in fish, which may impede recovery after anesthesia. ${ }^{21} \mathrm{~A}$ hypoxic state can also occur if the gills are not fully irrigated, causing gill filaments to collapse and become ischemic. Indeed, all water-quality parameters should be identical to the fish's normal tank water (e.g., $\mathrm{pH}$, salinity, hardness), and ideally the water used for anesthesia should be obtained from the home tank or aquarium system to reduce stress. Other factors such as temperature, body weight, and fish condition influence a fish's response to anesthesia.

\section{TYPES OF ANESTHETIC AGENTS}

A range of anesthetic agents are currently in use in laboratory, veterinary, and aquaculture contexts. The most common anesthetic drugs used in fish are MS-222 (Tricaine), benzocaine, isoeugenol, metomidate, 2-phenoxyethanol, and quinaldine. ${ }^{16-19}$ Experimental studies have explored the induction, recovery rate, and pharmocokinetics as well as undesirable or adverse side effects. However, these research investigations are limited to a relatively small number of species and caution should be applied when using any of these agents on a nonvalidated species. Fish are incredibly diverse, and a shift in water quality and environmental requirements can significantly influence the efficacy of an anesthetic agent. Therefore, low doses should be used initially with incremental increases until the most effective dose is achieved (Table 2). Although this review focuses on immersion anesthesia, injectable anesthetics are fairly common in larger species of fish. ${ }^{17}$ 
FIGURE 1. (A) Nerves in the tailfin of common carp (Cyprinus carpio) (x200). 1: nerve bundle, 2: blood vessel, 3: lepidotrichial hemisegment. (B) Detail from the red box in (A) shows a transverse section of the interior of the lepidotrichia segment of the tailray showing 2 nerves (EM, scale bar $=5 \mu \mathrm{m})$. (C) Nerve fibers in tailfin of common carp (TEM, scale bar=500 nm). Both C-fibers (1) and 3 categories of A-fibers (2) are present within the nerve. Schwann cell (3) producing the myelin sheets around A-fibers. Black spots in the neurite neuroplasm represent microtubules. C-fibers and A-fibers act as nociceptive afferents (adapted from Roques et al, 20106). (D) Section of the maxillary branch of the trigeminal nerve of rainbow trout showing the presence of A-delta and C-fibers that may act as nociceptors (x1000, scale bar $=2 \mu \mathrm{m}$; adapted from Sneddon, 20023).
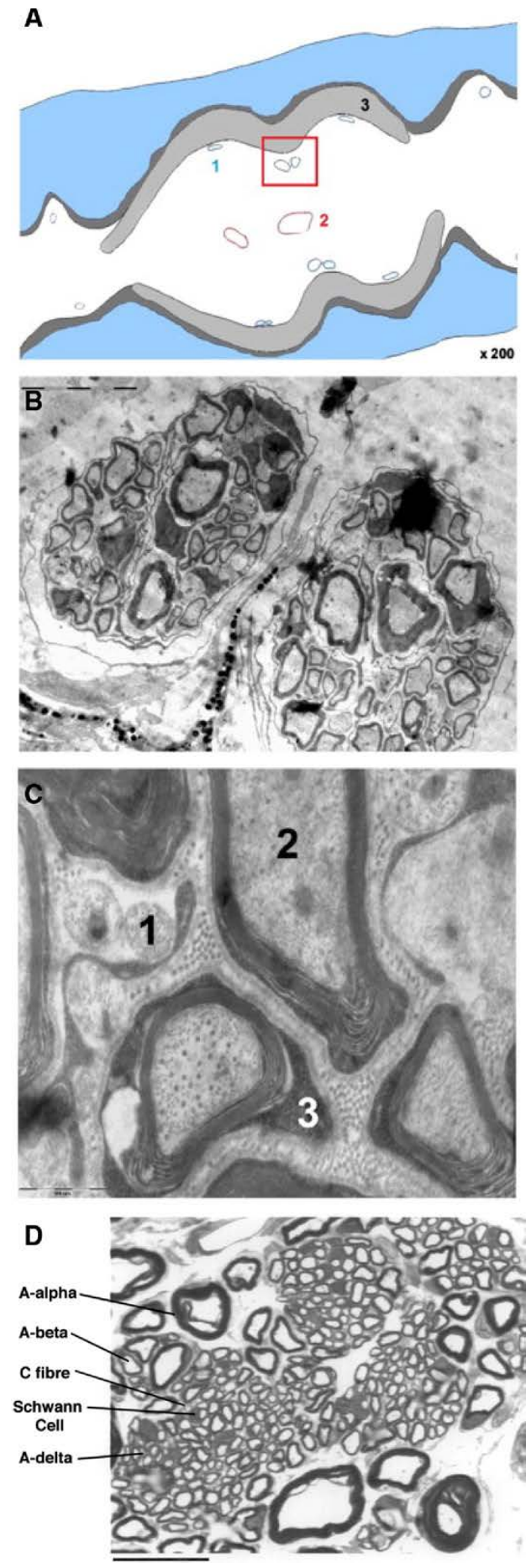
FIGURE 2. The mean time ( \pm SE) rainbow trout (Oncorhynchus mykiss) took to resume feeding after being shamhandled but not injected (control), injected with only saline solution, or only morphine, or only acid or acid plus morphine $\left({ }^{\star} P<.05\right.$; modified from Sneddon $2003^{13}$

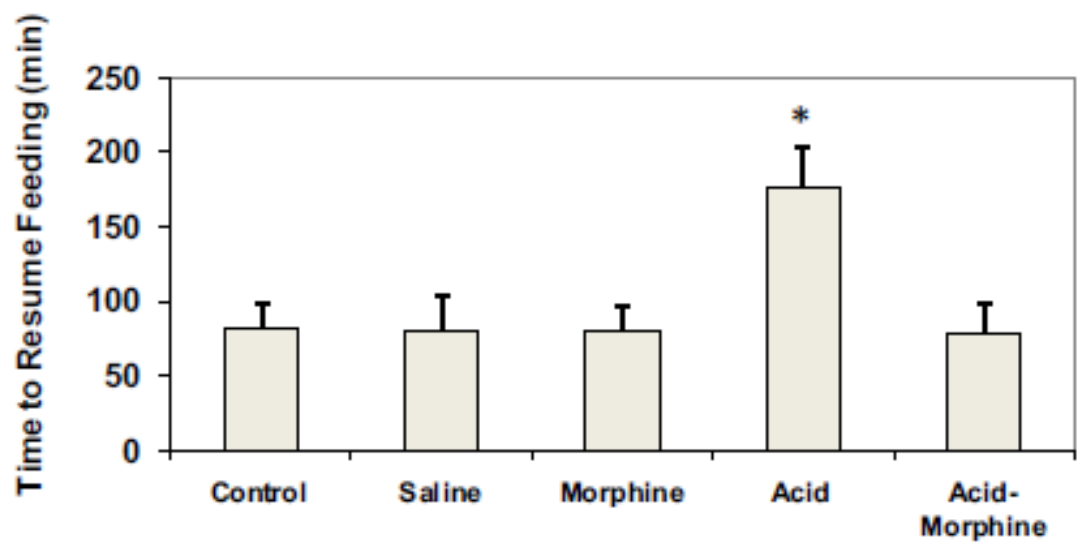

\section{MS-222 and Benzocaine}

This class of drugs is routinely used in clinical and veterinary medicine as topical analgesics. MS-222 (ethyl 3-aminobenzoate, tricaine methanesulphonate, metacaine) and benzocaine (ethyl 4aminobenzoate) are the 2 most common anesthetic agents used in fish research studies and are also used in food fish production. Both drugs are approved for aquaculture use in several countries including the United States and Norway. These local anesthetics inhibit the initiation and propagation of action potentials by blocking voltage-sensitive sodium channels. ${ }^{22,23}$ Administration of MS-222 and benzocaine is usually via immersion, entering the body via gill uptake and producing anesthesia by impeding neuronal signal transmission peripherally to the central nervous system. In fish, the precise action of these agents is not fully known. ${ }^{24-26}$ Benzocaine is structurally similar to the chemical composition of MS-222; however, this agent must first be dissolved in an organic solvent (usually ethanol), whereas MS-222 is soluble in water but has an acidic $\mathrm{pH}$ that requires addition of a buffer (i.e., sodium bicarbonate is usually added to obtain the desired $\mathrm{pH}$ ). Dosages of both drugs vary between species. For example, in Atlantic salmon (Salmo salar) MS-222 is administered at $65 \mathrm{mg} / \mathrm{L}$, as is benzocaine, ${ }^{27}$ whereas in halibut (Hippoglossus hippoglossus), ${ }^{28} \mathrm{MS}-222$ is given at $80 \mathrm{mg} / \mathrm{L}$ and benzocaine at $40 \mathrm{mg} / \mathrm{L}$; and in cod (Gadus morhua) MS-222 and benzocaine are administered at $60 \mathrm{mg} / \mathrm{L}$ and $25 \mathrm{mg} / \mathrm{L}$, respectively. ${ }^{29}$ Increased heart rate and respiration are observed in the initial phase of anesthesia using these drugs, as well as hyperglycemia, and are followed by a depression of heart rate and ventilation. ${ }^{30,31}$ Side effects include hypoxemia, hypoglycemia, and increased levels of lactic acid, suggesting a reliance on anaerobic metabolism, increased hematocrit, and hemoglobin values, as well as erythrocyte swelling. ${ }^{21,31-36}$ Plasma catecholamine values increase in some species, suggesting a possible stress response..$^{33,37,38}$

\section{Metomidate}

Metomidate hydrochloride (methyl 3-[1-phenylethyl] imidazole-4-carboxylate hydrochloride) is a nonbarbiturate hypnotic that activates and modulates inhibitory gamma-aminobutyric acid type A (GABAA) receptors and is a methyl analog of the imidazole derivative etomidate. This anesthetic agent is a centrally acting drug. ${ }^{39,40}$ Metomidate produces sedation and hypnosis in humans, 41 is a clinical and veterinary sedative ${ }^{42,43}$ and affects adrenal steroidogenesis inhibiting production of cortisol, ${ }^{44,45}$ which has 
been observed in fish. ${ }^{46,47}$ Deleterious effects of metomidate in fish are reduced respiration and circulation, subsequently leading to hypoxemia and reduced $\mathrm{pH}$ of the blood. ${ }^{21,30,33}$

TABLE 1. Descriptions of the stages of anesthesia and the parameters used to monitor anesthesia in fish. A number of procedures are provided as examples of what can be done to the fish under these levels of anesthesia

\begin{tabular}{|c|c|c|c|c|c|c|c|c|c|c|}
\hline Stage & Plane & $\begin{array}{c}\text { Level of } \\
\text { Anesthesia }\end{array}$ & $\begin{array}{c}\text { General } \\
\text { Demeanor }\end{array}$ & Activity & Equilibrium & $\begin{array}{c}\text { Gill } \\
\text { Ventilation } \\
\text { Rate }\end{array}$ & Reactivity & $\begin{array}{l}\text { Heart } \\
\text { Rate }\end{array}$ & $\begin{array}{l}\text { Muscle } \\
\text { Tone }\end{array}$ & $\begin{array}{l}\text { Examples of } \\
\text { Procedures }\end{array}$ \\
\hline 0 & & Normal & Normal & Normal & Normal & Normal & Normal & Normal & Normal & \\
\hline I & & $\begin{array}{l}\text { Lightly } \\
\text { sedated }\end{array}$ & Disoriented & Reduced & Normal & Normal & & Normal & Normal & \\
\hline II & & Excitation & Agitated & Increased & Difficulty & Increased & Increased & Increased & Normal & \\
\hline \multirow[t]{3}{*}{ III } & 1 & $\begin{array}{l}\text { Light } \\
\text { anesthesia }\end{array}$ & Anesthetized & None & Loss & Decreased & $\begin{array}{c}\text { Reflex } \\
\text { responses } \dagger\end{array}$ & Regular & Decreased & $\begin{array}{l}\text { Weight; close } \\
\text { visual inspection; } \\
\text { external } \\
\text { noninvasive tags, } \\
\text { gill scrape }\end{array}$ \\
\hline & 2 & Surgical $^{*}$ & Anesthetized & None & Loss & Shallow & None & Reduced & Decreased & $\begin{array}{l}\text { Invasive tags; } \\
\text { tissue removal; } \\
\text { injection; blood } \\
\text { sampling; gill } \\
\text { biopsy, lesion } \\
\text { dressing, recovery } \\
\text { surgerył }\end{array}$ \\
\hline & 3 & Deep & Anesthetized & None & Loss & $\begin{array}{c}\text { Rare } \\
\text { movements }\end{array}$ & None & Reduced & Relaxed & $\begin{array}{l}\text { Non-recovery } \\
\text { surgerył }\end{array}$ \\
\hline IV & & Overdose & $\begin{array}{l}\text { Apparently } \\
\text { dead }\end{array}$ & None & Loss & None & None & $\begin{array}{l}\text { Cardiac } \\
\text { failure }\end{array}$ & None & \\
\hline \multicolumn{11}{|c|}{ Adapted from Bell, $1987^{92}$; Burka et al, $1997^{48}$; McFarland, $1959^{93}$; McFarland and Klontz, $1969^{94}$; Summerfelt and Smith, $1990^{19}$. } \\
\hline
\end{tabular}

\section{2-Phenoxyethanol}

2-Phenoxyethanol is commonly used as a preservative in vaccines, skin products, and perfumes. The precise mode of action of this anesthetic in fish is unknown, but it may involve an expansion of neuronal cell membranes ${ }^{48}$ and, therefore, may suppress activity in the central nervous system. Side effects include impaired ventilation, reduced cardiovascular responses, lowered blood $\mathrm{O}_{2}$, increased $\mathrm{CO}_{2}$, and reduced $\mathrm{pH}$, as well as a possible stress response including higher concentrations of plasma adrenaline and glucose. ${ }^{33,49}$ 2-Phenoxyethanol also reduces immune function of the animal in which it is used. ${ }^{50}$ 
TABLE 2. Summary of selected anesthetic agents used in fish showing the range of doses, used in a variety of species and the resultant side effects (see Neiffer and Stamper, 200917 for species-specific information and also the citations in text)

\begin{tabular}{|c|c|c|c|}
\hline \multirow{2}{*}{ Anesthetic Agent } & \multirow{2}{*}{$\begin{array}{l}\text { Dose } \\
\left(\mathrm{mg} / \mathrm{L}^{-1}\right)\end{array}$} & \multicolumn{2}{|r|}{ Side Effects } \\
\hline & & Initial & Secondary \\
\hline MS-222 & $50-400$ & $\begin{array}{l}\text { Tachycardia } \\
\text { Increased } \\
\text { respiration } \\
\text { Hyperglycemia }\end{array}$ & $\begin{array}{l}\text { Decreased cardiovascular responses } \\
\text { Hypoglycemia } \\
\text { Increased lactate, hematocrit, and catecholamines } \\
\text { Erythrocyte swelling }\end{array}$ \\
\hline Benzocaine & $25-150$ & $\begin{array}{l}\text { Tachycardia } \\
\text { Increased } \\
\text { respiration } \\
\text { Hyperglycemia }\end{array}$ & $\begin{array}{l}\text { Decreased cardiovascular responses } \\
\text { Hypoglycemia } \\
\text { Increased lactate, hematocrit, and catecholamines } \\
\text { Erythrocyte swelling } \\
\text { Suppressed immune function }\end{array}$ \\
\hline Clove Oil & $4-150$ & & Decreased ventilation and cardiovascular responses \\
\hline Eugenol & $20-200$ & & Increased catecholamines and hematocrit \\
\hline Isoeugenol & $3.6-120$ & & \\
\hline Metomidate & $0.06-10$ & & $\begin{array}{l}\text { Reduced adrenal steroid production leading to } \\
\text { reduced cortisol } \\
\text { Reduced respiration, circulation, and } \mathrm{pH} \text { of blood } \\
\text { Hypoxemia }\end{array}$ \\
\hline 2-Phenoxyethanol & $0.25-600$ & & $\begin{array}{l}\text { Decreased ventilation rate, heart rate, blood } \\
\text { pressure, and blood pH } \\
\text { Increased adrenal hormones } \\
\text { Hyperglycemia } \\
\text { Reduced immune function }\end{array}$ \\
\hline Quinaldine & $10-50$ & Tachycardia & Decreased heart rate and respiratory function \\
\hline Quinaldine sulphate & $5-100$ & & $\begin{array}{l}\text { Increased cortisol and serum immunoglobulin M } \\
\text { Hyperglycemia }\end{array}$ \\
\hline $\begin{array}{l}\text { These doses are not } \\
\text { physiological state } m \\
\text { lowest doses and lov }\end{array}$ & propriate & all species or & $\begin{array}{l}\text { all conditions (e.g., temperature, body size, and } \\
\text { hen working with unfamiliar species or agents, use the } \\
\text { efficacy. }\end{array}$ \\
\hline
\end{tabular}




\section{Isoeugenol}

Isoeugenol (2-methoxy-4-prop-1-enyl-phenol), a component of clove oil, is structurally similar to eugenol, a potent analgesic used in dentistry. This anesthetic agent impedes sodium, potassium, and calcium channels, inhibits N-methyl D-aspartate (NMDA) receptors, and potentiates GABA A receptors. ${ }^{51-55}$ Isoeugenol has become a commonly used fish anesthetic and is the active ingredient in Aqui-S (Aqui-S New Zealand LTD, Lower Hutt, New Zealand); it is also an approved drug in some countries for use in aquaculture. Detrimental side effects of isoeugenol include impaired ventilation and depression of the cardiovascular system, which result in slower heart rate, decreased cardiac output, and reduced blood pressure. ${ }^{21,30}$ Increased plasma catecholamines and increased hematocrit may indicate a stress response elicited by the use of this anesthetic agent. ${ }^{21}$

\section{Quinaldine}

The quinoline family of compounds has antiseptic and antipyretic properties and is used in a variety of preparations, including antimalarial medicines. Quinaldine (2-methylquinoline) has been used to anesthetize fish for many years, but its mode of action is unknown. Initially, fish display a tachycardia; however, this is soon followed by bradycardia and impaired respiration. ${ }^{56}$ Elevated stress responses have also been recorded. ${ }^{34,50}$

FIGURE 3. Mean induction time (s \pm SE) of Atlantic cod (Gadus morhua) of body size $100 \mathrm{~g}$ and $1000 \mathrm{~g}$ anesthetized at $8^{\circ} \mathrm{C}$ and $16^{\circ} \mathrm{C}$ with benzocaine (BZ), MS-222 (MS222), metomidate (Met), and 2phenoxyethanol (2-phe) administered individually. Induction time is defined as time from submersion in the anesthesia bath to total loss of equilibrium. For benzocaine (1000-8C not tested) and MS-222, induction times were found to increase with increasing body weight but not for metomidate or 2-phenoxyethanol. Induction rates were shorter at $16^{\circ} \mathrm{C}$ than at $8^{\circ} \mathrm{C}$ except for 2-phenoxyethanol in the $1000 \mathrm{~g}$ fish (adapted from Zahl et al, 200929).

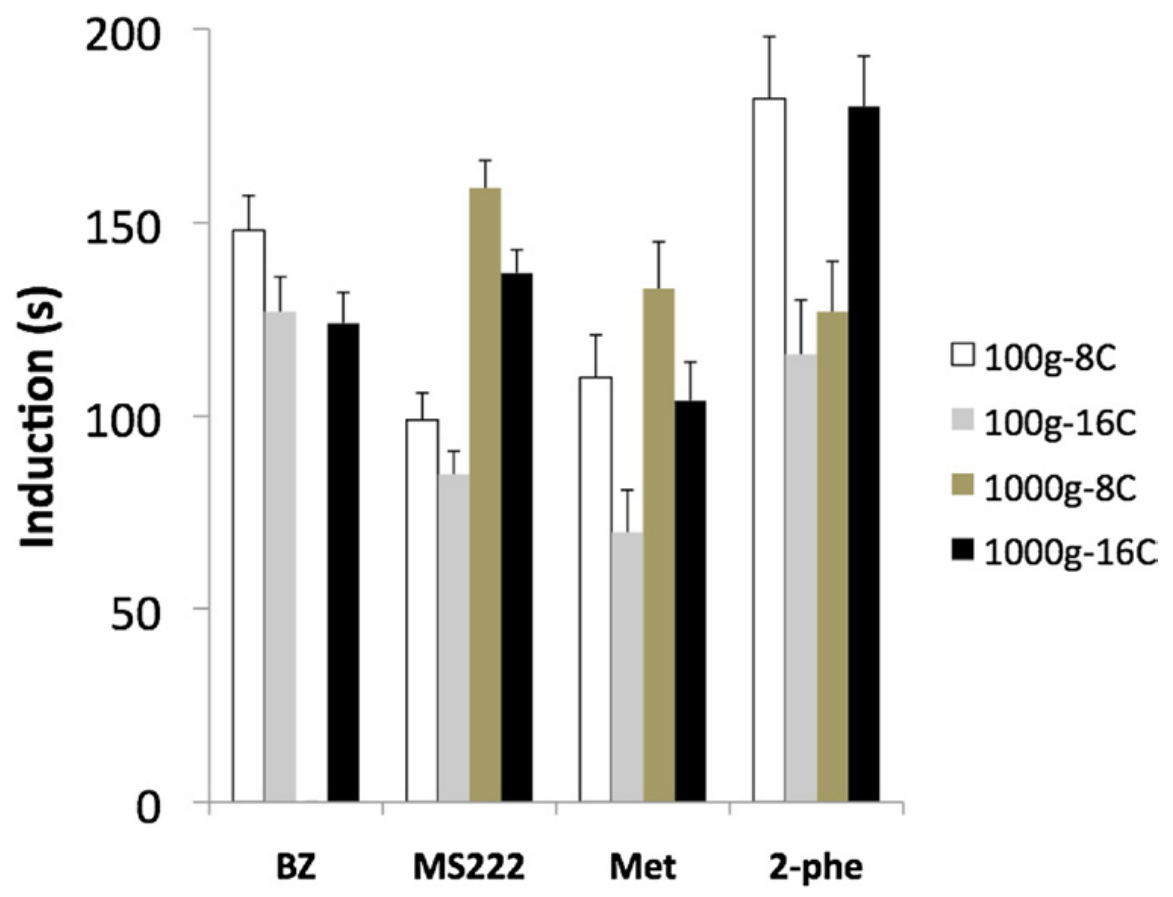




\section{ADMINISTRATION OF ANESTHETIC AGENTS}

Generally, the anesthetic drugs discussed above are administered as a single agent in fish. However, in veterinary and clinical practice, combining agents with different properties provides a more complete anesthesia than one single drug alone. Complementary effects between the different agents can result in safer, lower doses. In some cases, induction and recovery are improved and adverse side effects are reduced. ${ }^{57}$ Combination anesthesia has been explored in fish. For example, MS-222 and quinaldine administered to rainbow trout (Oncorhynchus mykiss) and northern pike (Esox lucius) resulted in less mortality and adverse side effects. ${ }^{58}$ Quinaldine used with diazepam (dose range, 0.6-1.2 parts per million) lowered the dose of both agents when anesthetizing gilthead sea bream (Sparus aurata) and European sea bass (Dicentrarchus labrax) ${ }^{59,60}$ This drug combination also reduced the mortality rate and undesirable effects of quinaldine in the 2 fish species in which it was investigated. ${ }^{59,60}$ MS-222 immersion anesthesia combined with intraoperative injections of local analgesics has been used during surgical procedures in koi carp (Cyprinus carpio) ${ }^{61}$ Administration of butorphanol improved subsequent behavior and recovery, whereas ketoprofen reduced muscle damage; therefore, their use may be beneficial. This approach was also effective in Atlantic cod when they were administered a combination of metomidate and either benzocaine or MS-222. ${ }^{29}$ Recovery times were much faster with a combination of these agents than one alone. In halibut, combination anesthesia also allowed the dose of each anesthetic drug used to be reduced. Improvements in induction and recovery rates were dependent on body size, with smaller fish having quicker induction times but larger fish exhibiting a much faster recovery rate compared with the use of one agent. ${ }^{28}$ Thus, combination anesthesia may be safer because this allows a reduction in dose, which is generally reflected in better recovery and lower mortality rates along with reduced adverse side effects in some cases. More experimental studies are needed to develop reliable combination protocols on a greater variety of fish species.

\section{FACTORS AFFECTING ANESTHESIA}

Biological factors such as age, sex, body condition and weight, developmental stage, growth and physiological status, health, and reproductive condition, as well as abiotic factors such as water quality, temperature, and oxygenation affect the efficacy of fish anesthesia. In fish, body condition, water temperature, and physiological stress have been investigated to determine their precise effects on anesthesia.

\section{Body Condition}

Research investigations have focused on body weight because drug dosing is often relative to the weight of an animal. However, some experimental studies on fish conclude that there is no effect of weight on induction and recovery, ${ }^{62,63}$ whereas others have opposite findings (Fig 3). ${ }^{29,47,64}$ Larger body size in whitefish (Coregonus lavaretus) was found to be associated with decreased induction times; in contrast, larger-sized rainbow trout had longer induction times and there was no effect in Atlantic salmon or brown trout (Salmo trutta). ${ }^{65}$ Induction increased with greater body weight in Senegalese sole (Solea senegalensis) using isoeugenol, 2-phenoxyethanol, and metomidate, but not for MS-222 ${ }^{66}$ Yet, MS-222 and benzocaine action were affected by body weight in Atlantic cod; larger fish had longer induction and recovery times (Fig 3). ${ }^{29}$ Only recovery was affected by body size when using metomidate in Atlantic cod, whereas the characteristics of 2-phenoxyethanol anesthesia had no relationship with size. Thus, these agents appear to have species-specific differences in their action, and research into factors such as lipid solubility and lipid content of fish is needed to explore the mechanisms of these body weight relationships. 
FIGURE 4. Mean $(A)$ induction and $(B)$ recovery time ( $\pm S E$ ) in Atlantic halibut (Hippoglossus hippoglossus) anesthetized with benzocaine (BZ) and MS-222. Induction time is recorded in seconds and is defined as the time from submersion in the anesthesia bath to total loss of equilibrium. Recovery is defined as time from transfer to recovery bath to regain of equilibrium. Average body weight of the fish was $1243 \mathrm{~g}$, exposure time was 5 minutes, and water temperature was $8^{\circ} \mathrm{C}$ or $15^{\circ} \mathrm{C}$. Induction was significantly shorter at the higher temperature, but recovery was significantly longer (adapted from Zahl et al, 201191).
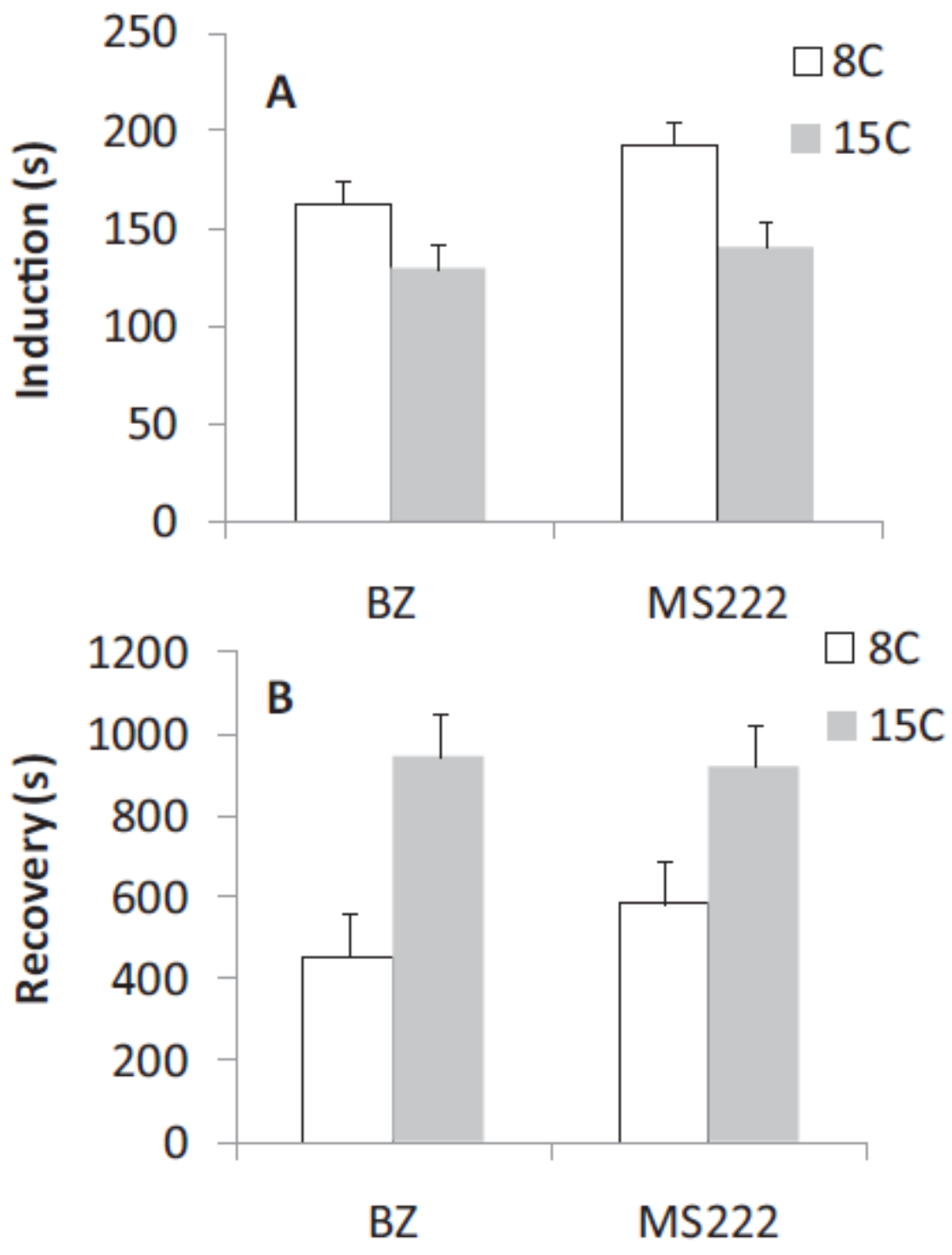

\section{Water Temperature}

Fish are poikilothermic and as such their physiology and metabolic rate are dependent on ambient water temperature. Studies have explored the impact water temperature has on the efficacy of anesthetic agents. Higher temperatures often reduce induction and recovery times. For example, isoeugenol in Atlantic salmon, brown trout, whitefish, perch (Perca fluviatilis), rainbow trout, and roach (Rutilus rutilus); benzocaine in striped bass (Morone saxatilis); 2-phenoxyethanol and isoeugenol in Atlantic cod, Atlantic halibut, European sea bass, and gilthead sea bream; and isoeugenol in rainbow trout have shorter 
induction and recovery rates at higher temperatures. ${ }^{29,63,65-69}$ MS-222 anesthesia is faster at higher temperatures in a variety of freshwater and marine fish. ${ }^{70-72}$ However, there is not a consistent simple relationship with water temperature relative to induction and recovery. For example, induction was much quicker in halibut at higher temperatures but recovery was more prolonged (Fig 4). Caution should be applied in regards to the relationship between water temperature and anesthesia. Furthermore, rapid changes in water temperature may cause stress to fish and effect their metabolic rate, circulation, and uptake of the anesthetic agent(s). ${ }^{29}$

FIGURE 5. Mean plasma cortisol concentrations ( \pm SE) of sunshine hybrid striped bass (Morone chrysops $\times$ M. saxatilis) exposed to low concentrations of several anesthetic agents for 15 minutes (Aqui-S; Clove oil, Clo; metomidate, met; MS-222; quinaldine sulfate, QS; quinaldine, Quin.

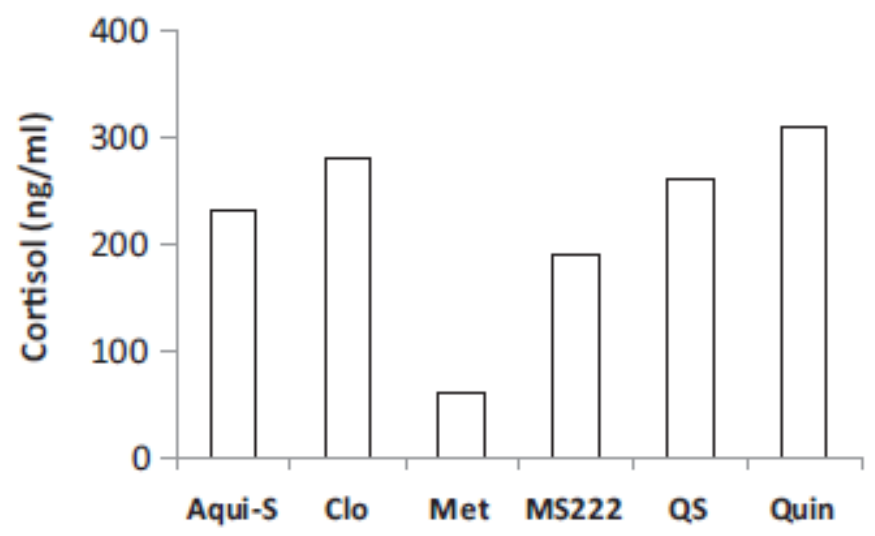

\section{Physiological Stress}

Anesthesia is profoundly affected by stress in fish. Stress results in increased cardiovascular responses and gill blood flow, producing greater diffusion of immersion anesthetic agents. Therefore, it is vital that stress is minimized before and during the anesthetic event. As outlined above, many anesthetic drugs elicit hormonal stress responses as a side effect (Fig 5). ${ }^{28,46}$ Acute stress before anesthesia with MS-222 in Atlantic cod resulted in shorter induction time and prolonged recovery. ${ }^{29} \mathrm{~A}$ deeper plane of anesthesia was observed in these fish after an acute stressor such that the dose of MS-222 was reduced to avoid mortality. However, the benefits of using anesthetic agents during potentially stressful procedures to render the fish unconscious are important to minimize any negative impacts on their welfare. Several studies have shown that handling stress is profoundly reduced when fish are anesthetized. ${ }^{46,73-78}$ Cortisol is elevated during handling in Atlantic salmon, but when anesthetized with metomidate, cortisol release is prevented. ${ }^{47}$ Therefore, the physiological status of the fish should be evaluated before anesthetizing the animal so that one can determine the most appropriate agent and dose. Monitoring of heart rate during prolonged procedures is advisable, especially during invasive surgery because this physiologic parameter is a direct reflection of the fish's level of anesthesia (Fig 6).

\section{ANALGESIA IN FISH}

In clinical and veterinary practice, analgesic drugs are administered to reduce pain and improve wellbeing, thereby promoting recovery of the patient. Analgesic protocols are available for a variety of animals, 57,70 but these drugs are generally not administered to fish. ${ }^{61,79}$ Research on teleost fish 
demonstrates that potentially painful events impair their normal behavior and may be indicative of discomfort. ${ }^{6-8,10,11,13,80,81}$ Prolonged changes in behavior have been observed, but relatively few studies have explored the use of analgesia to reduce these abnormal activities. The major classes of analgesic drugs are opioids, nonsteroidal anti-inflammatory drugs (NSAIDs), local anesthetics, and miscellaneous drugs that have pain-relieving properties (e.g., antidepressants). Only the first 3 classes have been explored as potential pain-relieving drugs in fish (Table 3).

FIGURE 6. An example of a laboratory set up where long-term anesthesia is maintained. Surgically anesthetized rainbow trout (Oncorhychus mykiss) are placed in a purpose-built cradle, covered with wet tissues to prevent drying out of the skin, held in place with Velcro straps, and fitted with a purpose-built mouthpiece and tubing to supply temperature controlled, aerated water. Heart rate is monitored via electrodes placed under both pectoral fins to gauge level of anesthesia along with reflex responses such as no response to tail pinch. This is taken from a nonrecovery procedure (photo by Dr P. J. Ashley in the Sneddon Laboratory).

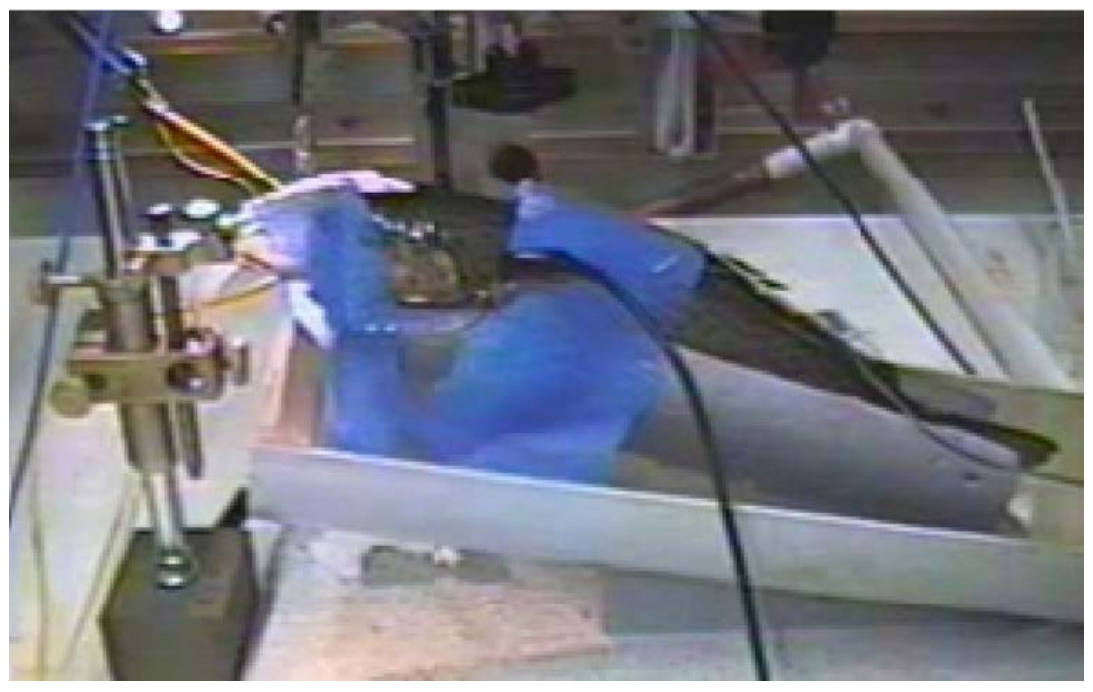

\section{Opioids}

Opioid drugs, typified by morphine, produce analgesia by acting on the 3 opioid receptors (mu, delta, and kappa) located on neuronal cell membranes. The presynaptic action of opioids inhibits neurotransmitter release, thereby blocking not only the activity of nociceptors but also centrally blocking transmission. Morphine administered to rainbow trout ameliorated the effects of a potentially painful stimulus; fish did not show a suspension in feeding and morphine reduced ventilatory responses and anomalous behaviors, which were exhibited by noxiously treated fish (Fig 2). ${ }^{13}$ Noxiously stimulated trout also do not show a neophobia to novel objects; however, morphine administration to noxiously treated fish resulted in normal fear responses during these tests. ${ }^{9}$ Therefore, it was concluded that morphine is an effective analgesic in rainbow trout. Morphine did not increase the temperature threshold in goldfish (Carassius auratus) in cases in which the fish performed an escape response to noxious heat but did ameliorate subsequent adverse changes in behavior of the fish in the tank after temperature threshold testing, which suggests morphine had a possible effect on reducing pain in these fish. ${ }^{12}$ Morphine behaves pharmocokinetically similar in fish compared with mammals; however, excretion rates are much slower (half-life of 37 hours and total elimination time of 56 hours) and morphine persists for a prolonged period 
after administration. ${ }^{82,83}$ This suggests that its use is favorable in chronic conditions or after major surgery because no further doses may be required.

TABLE 3. The analgesic drugs tested in fish showing the range of doses tested, the species of fish that these were tested on, side effects including whether the analgesic improved pain-related changes, and a comment on efficiency as an analgesic

\begin{tabular}{|c|c|c|c|c|}
\hline Analgesic & Dose & Species & Side Effects & Efficacy \\
\hline Lidocaine & $0.1-2 \mathrm{mg} / \mathrm{kg}$ & $\begin{array}{l}\text { Trout (IM) } \\
\text { Zebrafish (IM) }\end{array}$ & None observed & Very efficient at $1 \mathrm{mg} / \mathrm{kg}$ \\
\hline Morphine & $5-50 \mathrm{mg} / \mathrm{kg}$ & $\begin{array}{l}\text { Trout (IM) } \\
\text { Flounder (IP) } \\
\text { Goldfish (IM) }\end{array}$ & None observed & Very efficient at $5 \mathrm{mg} / \mathrm{kg}$ \\
\hline Buprenorphine & $0.01-0.1 \mathrm{mg} / \mathrm{kg}$ & Trout (IM) & $\begin{array}{l}\text { Reduced activity } \\
\text { No impact on } \\
\text { feeding or ventilation }\end{array}$ & Not efficient \\
\hline Carprofen & $1-5 \mathrm{mg} / \mathrm{kg}$ & Trout (IM) & $\begin{array}{l}\text { Depressed activity } \\
\text { Increased ventilation }\end{array}$ & $\begin{array}{l}\text { Reduced time to feed using } \\
2.5 \mathrm{mg} / \mathrm{kg}\end{array}$ \\
\hline Butorphanol & $0.25-5 \mathrm{mg} / \mathrm{kg}$ & $\begin{array}{l}\text { Koi carp }(0.4 ; \text { IM) } \\
\text { Dogfish (IM) }\end{array}$ & & $\begin{array}{l}\text { Dogfish - not efficient } \\
\text { Improved behavior in Koi }\end{array}$ \\
\hline Ketoprofen & $1-4 \mathrm{mg} / \mathrm{kg}$ & $\begin{array}{l}\text { Koi carp (2; IM) } \\
\text { Dogfish (IM) }\end{array}$ & $\begin{array}{l}\text { No impact on } \\
\text { behavior in Koi }\end{array}$ & Not efficient \\
\hline $\begin{array}{l}\text { Adapted from S } \\
\text { Mettam et al, } 2 C \\
\text { Abbreviations: I }\end{array}$ & $\begin{array}{l}\text { ddon, } 2003^{13} ; \mathrm{H} \\
\mathrm{L}^{14} ; \text { Nordgreen e } \\
\text { Intramuscularly }\end{array}$ & $\begin{array}{l}\text { rms et al, } 2005^{61} ; \mathrm{D} \\
\text { al, 2009 } \\
\text { IP, Intraperitoneally }\end{array}$ & $\begin{array}{l}\text { avis et al, } 2006^{86} ; \text { Newb } \\
\text { unpub. data. }\end{array}$ & et al, $2006^{82}$; Newby et al, $2009^{83}$; \\
\hline
\end{tabular}

Studies have investigated reflex responses to electric shock using the opioids, tramadol, dermorphine, and $\beta$-casomorphin in cod, steelhead trout (Salmo mykiss), carp, and rainbow trout and have found a reduction in the magnitude of the response. ${ }^{84,85}$ Butorphanol has been explored in the chain dogfish (Scyliorhinus rotifer) and koi carp as part of a combined anesthetic protocol; however, it appeared to have limited effectiveness. ${ }^{61,86}$ Buprenorphine was found to have poor analgesic properties in rainbow trout. ${ }^{14}$ Nonsteroidal Anti-inflammatories The NSAID class of drugs works by inhibiting arachidonate cyclooxygenase (COX) enzymes to reduce the production of thromboxanes and prostaglandins, providing antiinflammatory, antipyretic, and analgesic properties. ${ }^{57,87}$ Very few NSAIDs have been evaluated with respect to analgesia in fish. Ketoprofen was used in the chain dogfish to determine the minimum 
anesthetic concentration of MS-222 to prevent a response to an acute noxious stimulus; however, this approach was not effective. ${ }^{86}$ Ketoprofen did reduce the indicators of muscle damage postsurgery in koi carp but did not ameliorate subsequent behavioral changes. ${ }^{61}$ Carprofen was investigated in rainbow trout that exhibited pain and the fish resumed feeding more quickly than fish with no analgesia. However, when a $5.0 \mathrm{mg} / \mathrm{kg}$ carprofen dose was administered to rainbow trout, the fish were found to have depressed activity, even in control fish, and as such may be a deleterious side effect (Table 3). ${ }^{14}$ NSAIDs require further investigation if they are to be recommended as a reliable, effective analgesic in fish. The chronic use of NSAID analgesic drugs in mammals, birds, and reptiles can result in gastric ulcers or renal disease, but these effects are currently unknown in fish.

\section{Local Anesthetic Agents}

Local anesthetic agents inhibit the propagation of action potentials by blocking sodium channels and by affecting membrane function. ${ }^{57,88,89}$ Therefore, local anesthetic drugs impede pain sensation by blocking nociceptive transmission. Relatively few studies have explored local anesthetic drugs; however, novocaine is known to reduce reflex responses in $\operatorname{cod}^{90}$; this alone is not considered sufficient evidence to recommend its use in vivo. Lidocaine has been explored in rainbow trout with substantial success (Table 3). ${ }^{14}$ Lidocaine at a dose of $1 \mathrm{mg} / \mathrm{kg}$ was effective in reducing all of the adverse behavioral and physiological responses to pain in this species. More research is necessary to test the wide range of local anesthetic agents on a range of fish species to construct reliable analgesic protocols.

\section{CONCLUSION}

A variety of anesthetic drugs have been investigated for their properties to provide effective anesthesia of fish. However, given the significant diversity of fish species and their associated environmental and physiological requirements, it would be prudent to apply caution when selecting an anesthetic agent. Tentative exploration of the correct dose is vital because many factors influence anesthetic action including body size, water temperature, and physiological status. Combination anesthesia requires more attention given the positive findings from a number of studies that demonstrate reduced mortality rates and lower doses, which also appears to result in reduced side effects and better recovery. Humane treatment of fish subject to tissue-damaging, invasive procedures demands that any pain and discomfort are reduced by the use of an analgesic agent. However, the development of robust, valid analgesic protocols requires further study given the limited number of scientific studies. Currently, only morphine and lidocaine can be recommended in one species, the rainbow trout. Therefore, analgesic drugs need to be investigated in a range of species to determine their applicability in a variety of patient conditions; this will also require the development of pain indicators specific to the pain type and fish species. ${ }^{8,79}$

\section{REFERENCES}

1. Ashley PJ, Sneddon LU, McCrohan CR: Nociception in fish: stimulus-response properties of receptors on the head of trout Oncorhynchus mykiss. Brain Res 1166:47-54, 2007

2. Ashley PJ, Sneddon LU, McCrohan CR: Properties of corneal receptors in a teleost fish. Neurosci Lett 410:165-168, 2006

3. Sneddon LU: Anatomical and electrophysiological analysis of the trigeminal nerve in a teleost fish, Oncorhynchus mykiss. Neurosci Lett 319:167-171, 2002

4. Sneddon LU: Trigeminal somatosensory innervation of the head of a teleost fish with particular reference to nociception. Brain Res 972:44-52, 2003 
5. Sneddon LU, Braithwaite VA, Gentle MJ: Do fishes have nociceptors? Evidence for the evolution of a vertebrate sensory system. Proc Roy Soc Lond Biol Sci 270:1115-1121, 2003

6. Roques JAC, Abbink W, Geurds F, et al: Tailfin clipping, a painful procedure: studies on Nile tilapia and common carp. Physiol Behav 101:533-540, 2010

7. Ashley PJ, Ringrose S, Edwards KL, et al: Effect of noxious stimulation upon antipredator responses and dominance status in rainbow trout. Anim Behav 77:403-410, 2009

8. Reilly SC, Quinn JP, Cossins AR, et al: Behavioural analysis of a nociceptive event in fish: comparisons between three species demonstrate specific responses. Appl Anim Behav Sci 114:248259, 2008

9. Sneddon LU, Braithwaite VA, Gentle MJ: Novel object test: examining nociception and fear in the rainbow trout. J Pain 4:431-440, 2003

10. Dunlop R, Millsopp S, Laming P: Avoidance learning in goldfish (Carassius auratus) and trout (Oncorhynchus mykiss) and implications for pain perception. Appl Anim Behav Sci 97:255-271, 2006

11. Millsopp S, Laming P: Trade-offs between feeding and shock avoidance in goldfish (Carassius auratus). Appl Anim Behav Sci 113:247-254, 2008

12. Nordgreen J, Garner JP, Janczak AM, et al: Thermonociception in fish: effects of two different doses of morphine on thermal threshold and post-test behaviour in goldfish (Carassius auratus). Appl Anim Behav Sci 119:101-107, 2009

13. Sneddon LU: The evidence for pain in fish: the use of morphine as an analgesic. Appl Anim Behav Sci 83:153-162, 2003

14. Mettam JM, Oulton LJ, McCrohan CR, et al: The efficacy of three types of analgesic drug in reducing pain in the rainbow trout, Oncorhynchus mykiss. Appl Anim Behav Sci (in press)

15. Schoettger RA, Julin AM: Efficacy of MS-222 as an anesthetic on four salmonids. Invest Fish Control 13:15, 1967

16. Ackerman PA, Morgan JD, Iwama GK: Anesthetics. CCAC guidelines on: The care and use of fish in research, teaching and testing, Canadian Council on Animal Care, Ottawa CA, 2005, Available at: http://www.ccac.ca/Documents/Standards/Guidelines/Fish.pdf. Accessed April 28, 2011

17. Neiffer DL, Stamper MA: Fish sedation, anesthesia, analgesia, and euthanasia: considerations, methods, and types of drugs. Ilar J 50:343-360, 2009

18. Ross LG, Ross B: Anaesthetic and Sedative Techniques for Aquatic Animals. Oxford, UK, Blackwell Publishing, p 222, 2008

19. Summerfelt RC, Smith LS: Anaesthesia and surgery and related techniques, in Schreck CB, Moyle PB (eds): Meth ods for Fish Biology. Bethesda, MD, American Fisheries Society, pp 213-272, 1990

20. Rose JD: The neurobehavioral nature of fishes and the question of awareness and pain. Rev Fisheries Sci 10:1-38, 2002

21. Hill JV, Forster ME: Cardiovascular responses of Chinook salmon (Oncorhynchus tshawytscha) during rapid anaesthetic induction and recovery. Comp Biochem Physiol C 137:167-177, 2004

22. Frazier DT, Narahashi T: Tricaine (MS-222): Effects on ionic conductances of squid axon membranes. Eur J Pharmacol 33:313-317, 1975

23. Neumcke B, Schwarz W, Stampfli R: Block of Na channels in the membrane of myelinated nerve by benzocaine. Pflugers Arch 390:230-236, 1981

24. Hara K, Sata T: The effects of the local anesthetics lidocaine and procaine on glycine and gammaaminobutyric acid receptors expressed in xenopus oocytes. Anesth Analg 104: 1434-1439, 2007

25. Hedrick MS, Winmill RE: Excitatory and inhibitory effects of tricaine (MS-222) on fictive breathing in isolated bullfrog brain stem. Am J Physiol Regul Integr Comp Physiol 284:R405-R412, 2003

26. Ueta K, Suzuki T, Sugimoto M, et al: Local anesthetics have different mechanisms and sites of action at recombinant 5-HT3 receptors. Reg Anesth Pain Med 32:462-470, 2007 
27. Kiessling A, Johansson D, Zahl $I H$, et al: Pharmacokinetics, plasma cortisol and effectiveness of benzocaine, MS-222 and isoeugenol measured in individual dorsal aorta-cannulated Atlantic salmon (Salmo salar) following bath administration. Aquaculture 286:301-308, 2009

28. Zahl IH, Kiessling A, Samuelsen OB, et al: Anaesthesia of Atlantic halibut (Hippoglossus hippoglossus)_effect of preanaesthetic sedation, and importance of body weight and water temperature. Aquaculture (in press)

29. Zahl IH, Kiessling A, Samuelsen OB, et al: Anaesthesia of Atlantic cod (Gadus morhua)—effect of pre-anaesthetic sedation, and importance of body weight, temperature and stress. Aquaculture 295:52-59, 2009

30. Hill JV, Davison W, Forster ME: The effects of fish anaesthetics (MS222, metomidate and AQUI-S) on heart ventricle, the cardiac vagus and branchial vessels from Chinook salmon (Oncorhynchus tshawytscha). Fish Physiol Biochem 27:19-28, 2002

31. Ryan S: The dynamics of MS-222 anaesthesia in a marine teleost (Pagrus auratus: Sparidae). Comp Biochem Physiol C 101:593-600, 1992

32. Holloway AC, Keene JL, Noakes DG, et al: Effects of clove oil and MS-222 on blood hormone profiles in rainbow trout Oncorhynchus mykiss, Walbaum. Aquacult Res 35: 1025-1030, 2004

33. Iwama GK, McGeer JC, Pawluk MP: The effects of 5 fish anesthetics on acid base balance, hematocrit, blood-gases, cortisol, and adrenaline in rainbow trout. Can J Zool 67:2065-2073, 1989

34. Ortuno J, Esteban MA, Meseguer J: Effects of four anaesthetics on the innate immune response of gilthead seabream (Sparus aurata L.). Fish Shellfish Immunol 12:49-59, 2002

35. Thomas P, Robertson L: Plasma-cortisol and glucose stress responses of red drum (Sciaenops ocellatus) to handling and shallow-water stressors and anesthesia with MS-222, quinaldine sulfate and metomidate. Aquaculture 96:69-86, 1991

36. Velisek J, Stejskal V, Kouril J, et al: Comparison of the effects of four anaesthetics on biochemical blood profiles of perch. Aquacult Res 40:354-361, 2009

37. Gingerich WH, Drottar KR: Plasma-catecholamine concentrations in rainbow trout (Salmo gairdneri) at rest and after anesthesia and surgery. Gen Comp Endocrinol 73:390-397, 1989

38. Wedemeyer GA: Stress of anesthesia with MS-222 and benzocaine in rainbow trout (Salmo gairdneri). J Fish Res Board Can 27:909-914, 1970

39. Ashton D, Wauquier A: Modulation of a GABA-ergic inhibitory circuit in the in vitro hippocampus by etomidate isomers. Anesth Analg 64:975-980, 1985

40. Yang J, Uchida I: Mechanisms of etomidate potentiation of GABAA receptor-gated currents in cultured postnatal hippocampal neurons. Neuroscience 73:69-78, 1996

41. Grasshoff C, Drexler B, Rudolph $U$, et al: Anaesthetic drugs: linking molecular actions to clinical effects. Curr Pharm Des 12:3665-3679, 2006

42. Ching KY, Baum CR: Newer agents for rapid sequence intubation etomidate and rocuronium. Pediatr Emerg Care 25:200-207, 2009

43. Darrouj J, Karma L, Arora R: Cardiovascular manifestations of sedatives and analgesics in the critical care unit. Am J Ther 16:339-353, 2009

44. Vanden Bossche H, Willemsens G, Cools W, et al: Effects of etomidate on steroid biosynthesis in subcellular fractions of bovine adrenals. Biochem Pharmacol 33:3861-3868, 1984

45. Wagner RL, White PF, Kan PB, et al: Inhibition of adrenal steroidogenesis by the anesthetic etomidate. N Engl J Med 310:1415-1421, 1984

46. Davis KB, Griffin BR: Physiological responses of hybrid striped bass under sedation by several anesthetics. Aquaculture 233:531-548, 2004

47. Olsen YA, Einarsdottir IE, Nilssen KJ: Metomidate anesthesia in Atlantic salmon, Salmo salar, prevents plasma cortisol increase during stress. Aquaculture 134:155-168, 1995

48. Burka JF, Hammell KL, Horsberg TE, et al: Drugs in salmonid aquaculture-a review. J Vet Pharmacol Ther 20: 333-349, 1997 
49. Lambooij B, Pilarczyk M, Bialowas $\mathrm{H}$, et al: Anaesthetic properties of propiscin (etomidate) and 2phenoxyethanol in the common carp (Cyprinus carpio L.), neural and behavioural measures. Aquacult Res 40:1328-1333, 2009

50. Cuesta A, Meseguer J, Esteban MA: Total serum immunoglobulin $M$ levels are affected by immunomodulators in seabream (Sparus aurata L.). Vet Immunol Immunopathol 101:203-210, 2004

51. Aoshima H, Hamamoto K: Potentiation of GABAA receptors expressed in Xenopus oocytes by perfume and phytoncid. Biosci Biotech Biochem 63:743-748, 1999

52. Lee MH, Yeon KY, Park CK, et al: Eugenol inhibits calcium currents in dental afferent neurons. J Dent Res 84:848-851, 2005

53. Li HY, Park CK, Jung SJ, et al: Eugenol inhibits $K_{\text {_ }}$ currents in trigeminal ganglion neurons. J Dent Res 86:898-902, 2007

54. Park CK, Li HY, Yeon KY, et al: Eugenol inhibits sodium currents in dental afferent neurons. J Dent Res 85:900-904, 2006

55. Wie MB, Won MH, Lee $\mathrm{KH}$, et al: Eugenol protects neuronal cells from excitotoxic and oxidative injury in primary cortical cultures. Neurosci Lett 225:93-96, 1997

56. Lochowitz RT, Miles HM, Hafemann DR: Anesthetic-induced variations in cardiac rate of the teleost, Salmo gairdneri. Gen Pharmacol 5:217-224, 1974

57. Rang HP, Dale MM, Ritter JM, et al: Pharmacology. London, Churchill Livingstone, p 797, 2003

58. Schoettger RA, Steucke EW: Synergic mixtures of MS-222 and quinaldine as anesthetics for rainbow trout and northern pike. Prog Fish-Cult 32:202-205, 1970

59. Kumlu M, Yanar M: Effects of the anaesthetic quinaldine sulphate and muscle relaxant diazepam on sea bream juveniles (Sparus aurata). Isr J Aquacult 51:143-147, 1999

60. Yanar M, Kumlu M: The anaesthetic's effects of quinaldine sulphate and/or diazepam on sea bass (Dicentrarchus labrax) juveniles. Turk J Vet Anim Sci 25:185-189, 2001

61. Harms CA, Lewbart GA, Swanson CR, et al: Behavioral and clinical pathology changes in koi carp (Cyprinus carpio) subjected to anesthesia and surgery with and without intra-operative analgesics. Comp Med 55:221-226, 2005

62. Houston $\mathrm{AH}$, Woods RJ: Blood concentrations of tricaine methane sulphonate in brook trout, Salvelinus fontinalis, during anesthetization, branchial irrigation, and recovery. J Fish Res Board Can 29:1344-1346, 1972

63. Stehly GR, Gingerich WH: Evaluation of AQUI-S (TM) (efficacy and minimum toxic concentration) as a fish anaesthetic sedative for public aquaculture in the United States. Aquacult Res 30:365-372, 1999

64. Gilderhus PA, Marking LL: Comparative efficacy of 16 anesthetic chemicals on rainbow trout. N Am J Fish Manag 7:288-292, 1987

65. Hoskonen $\mathrm{P}$, Pirhonen J: Temperature effects on anaesthesia with clove oil in six temperate-zone fishes. J Fish Biol 64:1136-1142, 2004

66. Weber RA, Peleteiro JB, Martin LOG, et al: The efficacy of 2-phenoxyethanol, metomidate, clove oil and MS-222 as anaesthetic agents in the Senegalese sole (Solea senegalensis Kaup 1858). Aquaculture 288:147-150, 2009

67. Gilderhus PA, Lemm CA, Woods LC: Benzocaine as an anesthetic for striped bass. Prog Fish-Cult 53:105-107, 1991

68. Mylonas CC, Cardinaletti G, Sigelaki I, et al: Comparative efficacy of clove oil and 2-phenoxyethanol as anesthetics in the aquaculture of European sea bass (Dicentrarchus labrax) and gilthead sea bream (Sparus aurata) at different temperatures. Aquaculture 246:467-481, 2005

69. Woolsey J, Holcomb M, Ingermann RL: Effect of temperature on clove oil anesthesia in steelhead fry. N Am J Aquacult 66:35-41, 2004

70. Fowler ME, Miller RE: Zoo and Wild Animal Medicine, Philadelphia, PA, W.B Saunders Co, 2003 
71. Hikasa Y, Takase K, Ogasawara T, et al: Anesthesia and recovery with tricaine methanesulfonate, eugenol and thiopental sodium in the carp, Cyprinus carpio. Jpn J Vet Sci 48:341-351, 1986

72. Sylvester JR, Holland LE: Influence of temperature, water hardness, and stocking density on MS-222 response in three species of fish. Prog Fish-Cult 44:138-141, 1982

73. Iversen M, Finstad B, McKinley RS, et al: The efficacy of metomidate, clove oil, Aqui-S (TM) and Benzoak (R) as anaesthetics in Atlantic salmon (Salmo salar L.) smolts, and their potential stressreducing capacity. Aquaculture 221:549-566, 2003

74. King WV, Hooper B, Hillsgrove S, et al: The use of clove oil, metomidate, tricaine methanesulphonate and 2-phenoxyethanol for inducing anaesthesia and their effect on the cortisol stress response in black sea bass (Centropristis striata L.). Aquat Res 36:1442-1449, 2005

75. Kreiberg $\mathrm{H}$, Powell $\mathrm{J}$ : Metomidate sedation reduces handling stress in Chinook salmon. World Aquacult 22:58-59, 1991

76. Small BC: Anesthetic efficacy of metomidate and comparison of plasma cortisol responses to tricaine methanesulfonate, quinaldine and clove oil anesthetized channel catfish Ictalurus punctatus. Aquaculture 218:177-185, 2003

77. Small BC: Effect of isoeugenol sedation on plasma cortisol, glucose, and lactate dynamics in channel catfish Ictalurus punctatus exposed to three stressors. Aquaculture 238: 469-481, 2004

78. Small BC, Chatakondi N: Routine measures of stress are reduced in mature channel catfish during and after AQUI-S anesthesia and recovery. N Am J Aquacult 67:72-78, 2005

79. Sneddon LU: Pain perception in fish: indicators and endpoints. Ilar J 50:338-342, 2009

80. Sneddon LU: Pain perception in fish. Fish Farmer. November/December ed, 2004

81. Sneddon LU: Ethics and welfare: pain perception in fish. Bull Eur Ass Fish Pathol 26:6-10, 2006

82. Newby NC, Mendonca PC, Gamperl K, et al: Pharmacokinetics of morphine in fish: winter flounder (Pseudopleuronectes americanus) and seawater-acclimated rainbow trout (Oncorhynchus mykiss). Comp Biochem Physiol C 143:275-283, 2006

83. Newby NC, Wilkie MP, Stevens ED: Morphine uptake, disposition, and analgesic efficacy in the common goldfish (Carassius auratus). Can J Zool 87:388-399, 2009

84. Chervova LS, Lapshin DN: Opioid modulation of pain threshold in fish. Doklady Biol Sci 375:590-591, 2000

85. Chervova LS, Lapshin DN, Kamenskii AA: Pain sensitivity of trout and analgesia induced by intranasal administration of dermorphine. Doklady Biol Sci 338:424-425, 1994

86. Davis MR, Mylniczenko N, Storms T, et al: Evaluation of intramuscular ketoprofen and butorphanol as analgesics in chain dogfish (Scyliorhinus retifer). Zoo Biol 25:491-500, 2006

87. Hudson C, Whay H, Huxley J: Recognition and management of pain in cattle. In Pract 30:126-134, 2008

88. Grant D: Pain Management in Small Animals (ed 1). Philadelphia, PA, Elsevier, 2006

89. Peck TE, Hill SA, Williams M: Pharmacology for Anaesthesia and Intensive Care (ed 2). London, UK, Greenwich Medical Media Ltd., 2004

90. Chervova LS: Pain sensitivity and behavior of fishes. J Ichthyol 37:98-102, 1997

91. Zahl IH, Kiessling A, Samuelsen OB, et al: Anesthesia induces stress in Atlantic salmon (Salmo salar), Atlantic cod (Gadus morhua) and Atlantic halibut (Hippoglossus hippoglossus). Fish Physiol Biochem 36:719-730, 2010

92. Bell G: An outline of anesthetic and anesthesia for salmonids, a guide for fish culturists in British Columbia. Can Tech Rep Fish Aquat Sci No. 1534, 1987

93. McFarland WN: A study of the effects of anaesthetics on the behaviour and physiology of fishes. Publ Inst Mar Sci 6:22-55, 1959

94. McFarland WN, Klontz GW: Anesthesia in fishes. Fed Proc 28:1535-1540, 1969 